\title{
Activities and Achievements of the Double Star Committee of the Société Astronomique de France
}

\author{
Jean-Louis Agati, Sébastien Caille, André Debackère, Pierre Durand, \\ Florent Losse, René Manté, Florence Mauroy, Pascal Mauroy, \\ Guy Morlet, Claude Pinlou, Maurice Salaman, Edgar Soulié, \\ Yvonne Thorel, and Jean-Claude Thorel
}

Société Astronomique de France 3, rue Beethoven, 75016 Paris, France email: jean-louis.agati@ujf-grenoble.fr, astroseb@wanadoo.fr, andre.debackere@free.fr, pierre.durand6@wanadoo.fr, florent.losse@libertysurf.fr, rene.mante@wanadoo.fr, pascal.mauroy@wanadoo.fr, gmorlet@noos.fr, claude.pinlou@tele2.fr, maurice.salaman@wanadoo.fr, edgar.soulie@tele2.fr, jc.thorel@wanadoo.fr

\section{French amateurs as precursors of the Double Star Committee}

In a synthesis article (see ref. below), the double star expert Paul COUTEAU put the work of French pioneers of double stars observation in the perspective of the double star work carried in the world. After Antoine Yvon VILLARCEAU and Camille FLAMMARION, one prominent pioneer of double stars was Robert JONCKHEERE (1888-1974), an amateur before circumstances prompted him to become a professional astronomer, who devoted his life to double stars. Kenneth Glyn Jones wrote a biography and Charles Fehrenbach his obituary. Jean-Claude Thorel studied his life and career in double star observations (see Section 10 below). In the 1930s, another precursor of the Commission des Étoiles Doubles, Maurice DURUY (1894-1984) invented the micrometer with a comparison star, and applied the diffraction micrometer invented by Ejnar Hertzsprung to the measure of double stars, which he regularly observed at Nancy with a 275-mm telescope, at Lyon with a 162-mm telescope and in his observatory of Beaume-Mêle with a 40-cm and later a 60-cm telescope at Le Rouret (Alpes-Maritimes). He measured standard pairs of the list of Paul Muller and published his measures in the Journal des Observateurs; these measures requested by Paul Muller aimed at comparisons of between observers. He also collaborated with the Webb Society of Great Britain; Glyn Jones published his astronomical biography. Already in 1924, the pediatrician Paul BAIZE (1901-1995) had started the measurement of double stars as an amateur. He was granted permission to measure them with the 38 -cm of the Paris Observatory and made an impressive number of measures during his long "career" (24044). He also made orbit calculations and established a formula for the calculation of dynamic parallaxes in 1946. He wrote articles explaining new observation techniques devoted to double stars in the magazine L'Astronomie and continued his astronomical activity until the beginning of the 1990s. Glyn Jones published an astronomical biography of Paul Baize. In the 1960s, Bernard CLOUET and the late Robert SAGOT (1910-2006) made double star observations for the book which was then in preparation under the title La revue des constellations. Their measures remained unpublished; but publication of the measures made by Robert SAGOT is in preparation. At about the same time, the neurology professor Jacques LE BEAU (1908-1998) made the acquaintance of renowned professional astronomer Paul COUTEAU and learned from him how to measure double stars. Each year, he stayed for two weeks at Nice and conducted his observations with the $50-\mathrm{cm}$ refractor of the Nice 
Observatory. In 1978, Paul COUTEAU published the first book in French devoted to double stars: L'observation des étoiles doubles visuelles. That book triggered the interest of more amateur astronomers for double stars and indirectly influenced the creation of a group of double star observers which was transformed into the Commission des Étoiles Doubles.

\section{References:}

- Paul Baize, "52 Cygni, étoile double optique", L'Astronomie, vol. 38 (1924) p. 38

- Paul Baize, "Mesures d'étoiles doubles", L'Astronomie, vol. 38 (1924) p. 234

- Paul Baize, "La mesure des étoiles doubles et les petits instruments", L'Astronomie, vol. 43 (1929) pp. 453-460

- Paul Baize, "L'astronomie des étoiles doubles", L'Astronomie, vol. 44 (juin 1930) pp. 268-276; (août 1930) pp. 359-373; (septembre 1930) pp. 395-411; (novembre 1930) pp. 505-515

- Paul Baize, "Découverte récente d'étoile double", L’Astronomie, vol. 49 (mars 1935) pp. 142-144

- Paul Baize \& Lucien Romani, "Formules nouvelles pour le calcul des parallaxes dynamiques des couples orbitaux", Annales d'Astrophysique (Paris), vol. 9 (1946) p. 13

- Paul Baize, "Second catalogue d'orbites d'étoiles doubles visuelles", Journal des Observateurs, vol. 33 (1950) pp. 1-30

- Paul Baize, "Comment calculer une orbite d'étoile double", L'Astronomie, vol. 68 (janvier 1954), pp. 22-30

- Paul Baize, "Les binaires visuelles dont les éléments orbitaux ont été calculés", L'Astronomie, vol. 89 (juin 1975) pp. 253-262

- Paul Baize, "Les masses des étoiles variables à longue période", L'Astronomie, vol. 94 (février 1980) 71

- Paul Baize, "Note sur l'étoile double ADS 1959 = A 1818", L'Astronomie, vol. 95 (mars 1981), pp. 145-146

- Paul Couteau, "Quelques pionniers franais des étoiles doubles", Obs. $\&$ Travaux, no. 52 (juin 2000) pp. 14-16

- Maurice Duruy, "Étoiles doubles en mouvement", L'Astronomie, vol. 50 (juin 1936)

- Maurice Duruy, "Couples étalons d'étoiles doubles", Journal des Observateurs, vol. 22, no. 10 (octobre 1939) pp. 181-184

- Maurice Duruy, "Observations d'étoiles doubles faites en 1940", Journal des Observateurs, vol. 25, no. 5-6 (1942) p. 53

- Charles Fehrenbach, "Robert Jonckheere (1888-1974)", L'Astronomie, vol. 89 (1975) pp. $35-37$

- Kenneth Glyn Jones, "Biography of Paul Baize", p. 59-60; "Biography of Maurice Duruy", pp. 63-64; "Biography of Robert Jonckheere", p 68; in Webb Society Deep-Sky Observer's Handbook, Volume 1: Double Stars, Lutterworth Press, Guildford and London, 1979.

- Robert Sagot \& Jean Texereau, "La revue des constellations", Société Astronomique de France, Paris, 1961

\section{The creation and the life of the Commission des Étoiles Doubles}

In 1979, Pierre DURAND, a professor of future teachers, announced in the magazine L'Astronomie, published by the Société Astronomique de France, the creation of a group of amateur double star observers and aroused the interest of a few persons. This group met in 1980. With the support of professional astronomer Paul MULLER (1910-2000), this 
group was recognized in 1981 as a commission (committee) of the Société Astronomique de France. Pierre DURAND became its president and Frédéric HONNART its secretary. Paul MULLER and Paul COUTEAU became scientific advisers to the committee. Ever since, the Double Star Committee has constituted a forum of exchange of experiences and information in the field of double stars, particularly visual. In the summer of 1982, Pierre DURAND organized a first summer meeting at the Marseilles Observatory and in the summer of 1983, an observation workshop at the observatory of Aniane (Hérault). By an article in the magazine L'Astronomie, he encouraged amateur astronomers to turn their attention to double stars. Professional astronomers Pierre BACCHUS and Jean DOMMANGET joined the committee as scientific advisers. They soon suggested to its members to turn their efforts to binary stars which would be in the INPUT catalogue of the HIPPARCOS program; as a result of their suggestion, a call to observers of double stars was published in L'Astronomie. Their suggestion entailed three parts:

a) the position of a binary star in the binary star section of the INPUT catalogue was checked.

b) If the binary was found, binarity was confirmed for the INPUT catalogue. If the star seen at the given position was single, the observer was to search for the binary star and record its correct position.

c) the parameters of the pair $\rho$ and $\theta$ were measured.

Jean-Louis AGATI, Pierre DURAND, René-Georges HURET, Maurice SALAMAN, and Yvonne and Jean-Claude THOREL were among the first to take up this suggestion and to contribute to corrections of the INPUT catalogue. These corrections related to double stars made and amateurs resulted in a publication by Pierre BACCHUS. The preparation of the double star part of the INPUT catalogue led Jean DOMMANGET to the creation of the Catalogue de Composantes d'Étoiles Doubles et Multiples. Other professional astronomers also became scientific advisers to the committee: Frans van't VEER, Daniel BONNEAU, Marco SCARDIA, David VALLS-GABAUD and Josefina LING. The honorary president Paul BAIZE and the scientific advisers encouraged the amateurs to pursue observational goals which carry the perspective of scientifically useful results, such as the measurement of physical pairs for which an orbit calculation will become feasible within a few decades. With the initial impulse by Pierre DURAND and under the aegis of the committee, amateurs started missions at several French observatories: Bordeaux, Lille, Nice, Pic du Midi-de-Bigorre. For the past ten years, most missions were made at the Nice Observatory with the $50-\mathrm{cm}$ refractor. These missions have strongly stimulated the activities of observation and measurement of double stars. Following the creation of the committee, its board started the publication of projects and accounts in the magazine l'Astronomie. Double stars were once the subject of a game proposed to observers for the summer of 1984 (see Debackère). A very recent project raised up by Jean DOMMANGET has the purpose to eliminate the ambiguity pertaining to the node angle $\Omega$. Usually an orbit determination of a visual binary only provides a direction, namely an angle known $\pm 180^{\circ}$. If the signs of the radial velocities of the components are known, the ascendant node may be determined; therefore, the plane of the true orbit and the rotation axis of the couple may also be determined. This project implies the combination of visual orbits and radial velocities. Coordinated by Jean Dommanget and Daniel Bonneau, a group comprising Pierre Bacchus, Pascal Mauroy, Louis Pinatelle and Pierre Verhas has started work. 


\section{References:}

- Jean-Louis Agati, "Observation des étoiles doubles à l'aide d'une grille", Obs. E Travaux no. 4

- Jean-Louis Agati, "Annonce de la création de la Commission des Étoiles Doubles", L'Astronomie, vol. 95 (mai 1981) p. 241

- Jean-Louis Agati, "Appel aux observateurs d'étoiles doubles", L'Astronomie, vol. 99 (juin 1985), p. 288

- Pierre Bacchus, "Le colloque No. 98 de l'UAI à Paris", L'Astronomie, vol. 101 (1987) pp. 459-460

- Pierre Bacchus, "Les étoiles doubles et Hipparcos", L'Astronomie, vol. 102 (décembre 1988), pp. 499-502

- Paul Baize, "Sur quelques causes d'erreur dans les observations d'étoiles doubles. Vraies et fausses étoiles doubles", L'Astronomie, vol. 96 (janvier 1982) pp. 7-14

- Paul Baize, "La mesure des étoiles doubles par interférométrie speckle", L'Astronomie, vol. 96 (septembre1982), pp. 389-404; Errata, L'Astronomie, vol. 97 (mai 1983) p. 231

- Paul Baize, "Sur quelques étoiles doubles énigmatiques", L'Astronomie, vol. 97 (avril 1983) pp. 189-195; (mai 1983) pp. 223-230

- Paul Baize, "Où en est l'astronomie des étoiles doubles?", L'Astronomie, vol. 100 (janvier 1986) pp. 17-22

- Paul Baize, "Nouvelles de Sirius. Sirius B naine blanche", L'Astronomie, vol. 100 (février 1986) pp. 61-66; (juin 1986) pp. 181-185

- Paul Baize, "De l'amateur au professionnel. Souvenirs d'un dupliciste", L'Astronomie, vol. 101 (mai 1987) pp. 277-282

- Paul Baize \& Michel Petit, "Orbital binaries with variable components", $A \& A S$, vol. 77 (Mars 1989) 497

- Paul Baize, "Sur quelques problèmes posés par les étoiles doubles", L'Astronomie, vol. 106 (janvier 1992) p. 4 sqq.

- Daniel Bonneau, "Ursae Majoris, une étoile double pas si simple...", Obs. \& Travaux, no. 52 (juin 2000) pp. 8-13

- Daniel Bonneau, "Compte rendu de la réunion de la Commission des Étoiles Doubles tenue le 22 novembre 1981", L'Astronomie, vol. 96 (juin 1982) p. 312

- Daniel Bonneau, "Compte rendu de la réunion de la Commission des Étoiles Doubles tenue le 23 novembre 1985", L'Astronomie, vol. 100 (juillet-août 1986) p. 368

- André Debackère, "Observations des étoiles doubles de la constellation du Petit Cheval; résultat du jeu astronomique de l'été 1984 de la SAF", Obs. E Travaux, no. 14/15 (Troisième trimestre 1988) pp. 53-56

- Jean Dommanget, "L'astronomie des étoiles doubles à l'heure de l'astrométrie spatiale", L'Astronomie, vol. 96 (janvier 1982) pp. 15-27

- Jean Dommanget, "Space arrangement of the orbital planes of the visual double stars", ApESSS, vol. 142 (1988) pp. 171 sqq.

- Jean Dommanget \& Omer Nys, "Histoire d'un catalogue le CCDM", Obs. \& Travaux, no. 52 (juin 2000) pp. 26-31

- Jean Dommanget, "Les plans orbitaux des étoiles doubles visuelles et le milieu galactique", Ciel et Terre (Bruxelles), vol. 121 (2005) pp. 2-10

- Pierre Durand, "Pour la mesure des étoiles doubles, construction d'un micromètre pour amateur adaptable sur un télescope", L'Astronomie, vol. 93 (septembre 1979) pp. 375-380

- Pierre Durand, "Observer les étoiles doubles visuelles", L'Astronomie, vol. 99 (septembre 1985), pp. 409-414 
- Pierre Durand, "Réunion d'été de la Commission des Étoiles Doubles 23-24 août 1986", L'Astronomie, vol. 101 (mars 1987) pp. 158-159

- Pierre Durand, "Observations visuelles: le mur des 0",1 franchi!", L'Astronomie, vol. 101 (octobre 1987) p. 550

- Pierre Durand, "Vérification des nouvelles étoiles doubles Hipparcos", Obs. E

Travaux, no. 52 (juin 2000) pp. 32-33

- Pierre Durand, Joël Minois, \& Frédéric Honnart, "Activités de la Commission des Étoiles Doubles", L'Astronomie, vol. 96 (janvier 1982) pp. 28-29

- Jean Dommanget \& Omer Nys, "Catalogue de Composantes d'Étoiles Doubles et Multiples", Communications de l'Observatoire Royal de Belgique, Série A, no. 115 (1994), announced in IAU circular no. 125

- Ghislain de Froment, "Compte rendu de la réunion d'été de la Commission des Étoiles Doubles", L'Astronomie, vol. 100 (mai 1986) p. 246

- Ghislain de Froment, "Note sur ADS 8231 (BD +28 2022)", L'Astronomie, vol. 101 (février 1987) pp. 83-84

- Ghislain de Froment, "Mouvement relatif rectiligne de l'étoile double ADS 8231", Obs. ES Travaux, no. 10 (Deuxième trimestre 1987) pp. 55-58

- The Hipparcos Input Catalogue, European Space Agency Publication SP-1136, ESTEC, Noordwijk, Netherlands, march 1992

- Joël Minois, "Présentation du micromètre à diffraction de M. Duruy", L'Astronomie, vol. 98 (mai 1984), pp. 231-238; (contrary to the implicit statement of this title, the diffraction grid micrometer was invented by Ejnar Hertzprung. However, Maurice Duruy was the first to apply it to the measure of double stars.)

- Paul Muller, "Maurice Duruy (1894-1984)", L'Astronomie, vol. 99 (1985) p. 135

- Paul Muller, "Une Commission des étoiles doubles à la S.A.F.", L'Astronomie, vol. 96 (janvier 1982) pp. 3-6

- Paul Muller, "Un travail de Sisyphe: la recherche des étoiles doubles", L'Astronomie, vol. 100 (octobre 1986) pp. 445-453

- Paul Muller, "Un nouveau bilan de la réobservation des couples du catalogue d'étoiles doubles d'Aitken", Obs. \& Travaux, no. 37 (Premier trimestre 1994) pp. 32-34

- Marie-Claude Paskoff, "Des Lycéens dans les étoiles ... doubles", Obs. 6 Travaux, no. 52 (juin 2000) pp. 59-62

- Edgar Soulié, "Sur le passage des coordonnées cartésiennes aux coordonnées polaires en astronomie", Obs. E Travaux, no. 5 (Premier trimestre 1986) pp. 50-51

- Edgar Soulié, "Les astronomes amateurs et les étoiles doubles", Le Ciel, bulletin de la Société Astronomique de Liège, novembre 1999, pp. 268-272

- Jean-Claude Thorel, "Mesures d'étoiles doubles. Programme C.C.D.M.", Obs. \& Travaux, no. 40 (Dernier trimestre 1994) pp. 31-34

- Jean-Claude Thorel, "Commission des Étoiles Doubles, Règles de présentation des mesures d'étoiles doubles visuelles", Obs. $E$ Travaux, no. 40 (Dernier trimestre 1994) pp. 38-39

\section{Micrometric measurements with a filar micrometer}

Over many years, Pierre DURAND, Jacques LE BEAU, Yvonne and Jean-Claude THOREL made regular missions at Nice using the 50-cm refractor which is equipped with a filar micrometer with electronic recording. The $74-\mathrm{cm}$ refractor was used occasionally. Yvonne and Jean-Claude THOREL observed more than 650 pairs, made ca. 4000 measures and published more than 1300 mean positions. In the course of their observations, four new pairs were discovered (JCT 1 to 4 ). 


\section{References:}

- Omodeo Salé Angelo, "Détermination de l'échelle dans un micromètre à fils", Obs. \& Travaux, no. 11 (Troisième trimestre 1987) pp. 49-52

- André Debackère, "Observations de 54 étoiles doubles visuelles en 1986", Obs. \& Travaux, no. 16 (Dernier trimestre 1988) pp. 26-30

- Pierre Durand, "Mesures d'étoiles doubles à l'Observatoire de Nice en 1979 et 1982 (1ère série)", Obs. 6 Travaux, no. 13 (Premier trimestre 1988) pp. 27-29

- Frédéric Honnart, "Mesures d'étoiles doubles à l'équatorial de $35 \mathrm{~cm}$ du Laboratoire d'Astronomie de Lille", Obs $\&$ Travaux, no. 2 (1982), p. 40

- Jacques Le Beau, "Observation de 28 étoiles doubles visuelles en 1980-1981", Obs. \& Travaux, no. 1 (troisième trimestre 1982) pp. 24-26

- Jacques Le Beau, "Observation d'étoiles doubles visuelles en 1981-1982", Obs. \& Travaux, no. 3 (premier trimestre 1984) pp. 26-29

- Jacques Le Beau, "Observation d'étoiles doubles visuelles en 1982-1983. Mesure de 60 couples", Obs. \& Travaux, no. 5 (Premier trimestre 1986) pp. 45-49

- Jacques Le Beau, "Observation d'étoiles doubles visuelles en 1983-1984", Obs. \&6 Travaux, no. 7 (Troisième trimestre 1986) pp. 37-40

- Jacques Le Beau, "Mesures d'étoiles doubles visuelles (Nice, 1984)", Obs. $\&$ Travaux, no. 8 (Dernier trimestre 1986) pp. 40-45

- Jacques Le Beau, "Mesures d'étoiles doubles visuelles (Nice, 1985)", Obs. \& Travaux, no. 9 (Premier trimestre 1987) pp. 41-52

- Jacques Le Beau, "Mesures d'étoiles doubles visuelles (Nice, 1986)", Obs. E Travaux, no. 12 (Dernier trimestre 1987) pp. 37-44

- Jacques Le Beau, "Mesures d'étoiles doubles visuelles (Nice, 1987)", Obs. \& Travaux, no. 14/15 (Troisième trimestre 1988) pp. 40-49

- Jacques Le Beau, "Mesures (1090) de 435 étoiles doubles faites à Nice au réfracteur de $50 \mathrm{~cm} ", A \& A S, 77$ (1989) 125-130

- Jacques Le Beau, "Mesures (402) de 131 étoiles doubles faites à Nice au réfracteur de $50 \mathrm{~cm}$ 2è série)", A\& $A S, 85$ (1990) 889-894

- Jacques Le Beau, "Mesures (460) de 177 étoiles doubles visuelles (Nice 1989) avec L 50 cm", Obs. \& Travaux, no. 21 (1990) 39-44

- Jacques Le Beau, "Compagnons éloignés d'étoiles doubles serrées: Couples optiques ou couples physiques? 1984-1989", Obs. E Travaux, no. 22-23 (1990) 39-43

- Jacques Le Beau, "Mesures (209) de 104 étoiles doubles visuelles avec L 50 cm", Obs. \& Travaux, no. 26 (1991) 25-31

- Jacques Le Beau, "A propos de compagnons éloignés nouveaux de deux étoiles", Obs. \& Travaux, no. 28 (1991) 26-30

- Jacques Le Beau, "11 è série - Mesures (183) de 81 étoiles doubles visuelles avec L $50 \mathrm{~cm}$ à Nice en 1991", Obs. E Travaux, no. 30 (1992) 38-44

- Jacques Le Beau, "Remarques sur 10 nouveaux compagnons éloignés d'étoiles doubles visuelles", Obs. \& Travaux, no. 33 (1993) 21-28

- Jacques Le Beau, "12 è série - Mesures (139) de 63 étoiles doubles visuelles avec L 50 cm à Nice en 1992", Obs. E Travaux, no. 34 (1993) 19-24

- Jacques Le Beau, "Mesures (53) de 43 étoiles doubles visuelles (Nice 1993 - 13 è série)", Obs. E Travaux, no. 39 (1994) 13-17

- Jacques Le Beau, "A propos de 12 observations de couples optiques écartés dont 11 nouveaux", Obs. \& Travaux, no. 42 (1995) 2-10

- Jacques Le Beau, "Mesures (29) de 27 étoiles doubles visuelles (Nice 1994 - 14 è série)", Obs. E Travaux, no. 46 (1996) 37-41

- Michel Lefebvre, "Mesures d'étoiles doubles", Obs. $\&$ Travaux, no. 52 (2000) 81 
- Edouard Oblak \& Patricia Lampens, "Astrométrie et photométrie CCD d'étoiles doubles et multiples du catalogue HIPPARCOS", Obs. \& Travaux, no. 52 (2000) 34-43

- Jean-Claude Thorel, "L'observation des étoiles doubles à l'Observatoire de la Côte d'Azur", édition Obs. de la Côte d'Azur (1995).

- Jean-Claude Thorel, "Mesures d'étoiles doubles effectuées à la lunette de $50 \mathrm{~cm}$ de l'Observatoire de Nice (1ère série)", $A \& A S, 115$ (1996) 59.

- Jean-Claude Thorel, "Mesures d'étoiles doubles effectuées à la lunette de $50 \mathrm{~cm}$ de l'Observatoire de Nice (2ème série)", A\&AS, 132 (1998) 29-30

- Jean-Claude Thorel, "Discovery of JCT 4 AB", Commission 26 of the UAI circular no. 141 , june 2000

- Jean-Claude Thorel, "Mesures d'étoiles doubles faites à Nice (3ème série). Nouvelle étoile double JCT, et position de DOO 35", A\&AS, 147 (2000) 251

- Jean-Claude Thorel, "Rectification about JCT Fa (BD+60²74)", Commission 26 of the UAI circular no. 149, february 2003

\section{Photographic measurements of binary stars}

This technique was investigated by Pierre DURAND and Daniel SIMIER with a telescope having an aperture of $20 \mathrm{~cm}$. The late medicine professor Pierre JANNY (19211993) applied the photographic technique to the measure of double stars and constructed an apparatus to measure the images. This technique is now superseded by that based on the use of a charge coupled device (CCD).

\section{References:}

- Pierre Durand \& Daniel Simier, "La mesure photographique d'étoiles doubles", L'Astronomie, vol. 101 (mai 1987) pp. 265-276

- Pierre Janny, "Essais de mesure photographique des étoiles doubles avec un télescope de $20 \mathrm{~cm} "$, Obs. \& Travaux, no. 17 (1989) pp. 32-40

- Pierre Janny, "Mesures photographiques d'étoiles doubles", Obs. \& Travaux, no. 41 (Premier trimestre 1995) p. 196

\section{Measures by the transit method}

The transit method described by Pierre DURAND and André DEBACKERE appeared especially attractive because the only specific accessory which is required is a chronometer. This method was practised for several years by members of a group led by André DEBACKERE and comprising Jacques CAZENEUVE, Michel LEFEBVRE and the late Paul VIEL. Great care was taken to evaluate the precision with which the parameters were determined. As shown by Paul VIEL, the precision obtained was less that that obtained with either a filar or a double-image micrometer. A few years later, Paul BAIZE independently said that, after a period of training, observers should leave this method for a more precise one - and get equipped with a micrometer.

\section{References:}

- Pierre Durand, "Mesure des binaires au chronomètre", L'Astronomie, décembre 1988, pp. 459-464; see also pages 685 and 686 of Les étoiles doubles et multiples, chapter XII of Astronomie: Le guide de l'observateur, coordinator Patrick Martinez, publisher Société d'Astronomie Populaire de Toulouse/ADAGIO, Toulouse, 1987

- André Debackère, "Méthodes simples de mesures d'étoiles doubles", Obs. \& Travaux, no. 35, Troisième trimestre 1993, pp. 39-46 


\section{The double image micrometer with a spar plate}

Between 1941 and 1943 at the observatory of Pic du Midi de Bigorre, the astronomer Bernard LYOT (1897-1952) devised a double image micrometer for the measurement of double stars. Henri CAMICHEL (1917-?) was the first to construct a micrometer based on his concept. He measured double stars with it at the observatory of Pic-duMidi-de-Bigorre between 1943 and 1946 and in the same article, he briefly described the micrometer and published his measures. This micrometer was used by Audouin DOLLFUS for the measurement of double stars at Pic-du-Midi-de-Bigorre in 1954 and later for the measurement of diameters of Jupiter's satellites. The principle of this micrometer is as follows: as a result of the birefringence of the spar plate with parallel faces, each component of a binary star produces two images. The plate may turn about its optical axis and also about a perpendicular axis. By orienting the plate, the observer can align the four images and have them equidistant. From the orientation of the plate, he can then deduce the position angle and the angular separation of the pair.

In 1988, under the direction of Jean-Louis AGATI, the Commission des Étoiles Doubles conceived a light (mass under 650 grams) and accurate micrometer based on the invention of Bernard Lyot. The rotation of the plate around a direction perpendicular to its optical axis is made with toothed wheels equipped with an elastic device which cancels backlash; this device enables the accurate determination of the plate position. This model has been validated by observers who made good measures with it. The Commission arranged the fabrication of a small series of spar plate micrometers by the MECA-PRECIS company. A score of micrometers were sold to European amateurs.

Independently, Paul MULLER invented another type of double image micrometer, which uses two birefringent half prisms, glued together. This micrometer has been used by professional astronomers.

\section{References:}

- Jean-Louis Agati \& René-Georges Huret, "Le micromètre à double image à lame de spath", L'Astronomie, décembre 1988; pp. 482-489

- Henri Camichel, "Mesures d'étoiles doubles faites au Pic du Midi", Journal des Observateurs, vol. XXXII, No. 8-9 (1949), pp. 94-96

- Commission des Étoiles Doubles, "Notice d'utilisation du micromètre à lame de spath de Lyot", Société Astronomique de France, Paris, octobre 1991, 13 pages

- Commission des Etoiles Doubles, "Micromètre à double image à lame de spath de Lyot. Conditions d'emploi et spécifications techniques", Société Astronomique de France, Paris, mai 1995, 4 pages

- Audouin Dollfus, "L'observation à la tour Eiffel du passage de Mercure devant le Soleil pour la mesure de son diamètre", L'Astronomie, septembre 1954, pp. 337-345

- Paul Muller, "Un nouveau micromètre à double image", L'Astronomie, vol. 61 (septembre 1947) pp. 265-266

- Edgar Soulié, "Een micrometer voor dubbelsterren", HEELAL, magazine of the Vereniging voor Sterrenkunde, Meteorologie, Geofisica en aanverwante Wetenschappen, (Brussels) no. 366, maart 1988, p. 50

- Edgar Soulié, "Fabbricazione in serie di un micrometro a doppia immagine di Lyot e Camichel", Bolletino della Società Astronomica Italiana, no. 1, marzo 1988, pp. 27-28

- Edgar Soulié, "Un micromètre à double image de Lyot et Camichel pour la mesure des étoiles doubles. Projet de fabrication en série de la Commission des Etoiles Doubles de la S.A.F.", Astro-Ciel, magazine of the Astro-Club de France, no. 18, mars-avril 1988. p. 26 
- Edgar Soulié, "Un micromètre pour la mesure des étoiles doubles", L'Astronomie, volume 102, avril 1988, p. 161

- Edgar Soulié, "Proposal to make a line of micrometers", Journal of the Royal Astronomical Society of Canada, vol. 82, no. 2, april 1988, pp. 82-83

- Edgar Soulié, "Projet de la Commission des Étoiles Doubles de la SAF: Fabrication en série d'un micromètre", Ciel et Terre, vol. 104, no. 3 (mai-juin 1988) p. 70

- Edgar Soulié, "Micrometro per dilettanti. Una proposta della Societa Astronomica francese, L'astronomia (Italy), no. 78, giugno 1988, pp. 72-73

- Edgar Soulié, "Ein Doppelbildmikrometer nach Lyot und Camichel zur Doppelsternvermessung", Sterne und Weltraum, no. 7-8/88 Juli-August 1988, p. 461

- Edgar Soulié, "A Double-image Micrometer", Monthly Notices of the Astronomical Society of Southern Africa, vol. 47, no. 7 and 8 august 1988, pp. 74-76

- Edgar Soulié, "Mikrometer till observatoriet", Astro, magazine of the Svensk Amator Astronomisk Forening (Sweden), no. 4, 1988, p. 9

- Edgar Soulié, "El micrometro de doble imagen de Lyot y Camichel para la medida de estrellas dobles: proyecto de fabricacion en serie", Bulletin of the Agrupacion Astronomica de Madrid, vol. 80, mayo-junio 1988, pp. 15-17

- Edgar Soulié, "Micrometers for double stars", Sky $\&$ Telescope (United-States), november 1988, p. 487

- Edgar Soulié, "Projetto della commissione delle stelle doppie della S.A.F. Fabbricazione in serie di un micrometro a doppia immagine di Lyot e Camichel", Orione (Italy) 1988, no. 4, pp. 6-7

- Edgar Soulié, "Micrometer voor beroeps- èn amateurastronomen" (translated by Gerrit Coddens), Zenit (Populair-wetenschappelijk maandblad over sterrenkunde, weerkunde, ruimtevaart en ruimteonderzoek) Netherlands, januar 1989, p. 32

- Edgar Soulié, "A double image micrometer after Lyot and Camichel for measuring binary stars". A design project of the Commission des Etoiles Doubles of the Société Astronomique de France, Journal of the British Astronomical Association, vol. 99, no. 1 (January 1989) pp. 31-32

- Edgar Soulié, "Fabrication en série d'un micromètre à double image de Lyot et Camichel", Orion, magazine of the Swiss Astronomical Society, no. 230, Februar 1989, pp. 13-14

- Edgar Soulié, "Voir double", Ciel et Espace, magazine of the Association Franaise d'Astronomie, no. 236, mai 1989, p. 15

- Edgar Soulié, "Et dobbeltbilledmikrometer efter Lyot og Camichel til malinger af dobbeltstjerner" (translated by Niels-P. Wieth-Knudsen) Astronomisk Tidsskrift (astronomical magazine common to Denmark, Finland, Norway and Sweden), ARG.22, Nr 2, 1989, pp. $72-73$

- Edgar Soulié, "Projekt Komisji Gwiazd Podwojnych S.A.F. Produkcja seryjna dwuobrazowego mikrometru Lyota i Camichela" (translated by the journal), Urania (Poland) 1989 no. 9 (572), pp. 274-277

- Edgar Soulié, "Fabrication en série d'un micromètre à double image de Lyot", Bulletin de l'Union des Physiciens, avril 1991, no. 733, pp. 697-701

- Niels Wieth-Knudsen, "Micromètre à double image. La dernière branche de l'arbre", Obs. ES Travaux, no. 52 (juin 2000) pp. 73-80 


\section{The application of CCD cameras and webcams to double stars and the data treatment with appropriate software}

In the 1980s, the cost of CCD cameras, which had been quite high, significantly decreased. At the same time, their use for astronomy became simpler. These two factors contributed to incite amateur astronomers to use them. Within the Double Star Committee of SAF, Guy MORLET, Maurice SALAMAN and the late Ghislain de FROMENT created a working group in 1990 to investigate their application to the measurement of pairs. Images were acquired thanks to two cameras of different brands (brand SBIG, model ST4; brand LE2IM, model HiSis22) at various places: Observatoire du MontChiran, Corsica, Observatoire de Haute-Provence. Several computer programs aimed at the determination of the position angle, the angular separation and the magnitude difference were tested, as well:

- a program developed by the Association Nationale Sciences Techniques Jeunesse in 1981

- a program based on the method of inertia moments, developed by Pierre Bacchus

- the program CERCLE developed in BASIC by Guy Morlet in 1995

These different programs gave good results for pairs whose angular separations is significantly larger than the resolution limit of the telescope, but they failed in the case of close pairs. The program QMIPS32 by Christian Buil was interesting because it enabled to process the image by the wavelet method to obtain a measure; but it implied many constrains for the user.

The program $S C A N$, developed by H. Jenkner and improved by D. Sinachopoulos, relied on a comparison between the profiles of observed and calculated illuminations along two directions which are parallel to the image sides. But this program was ineffectual when the segment joining the pair components is roughly parallel to a side of the image. Its existence suggested the development of a program which would compare the maps of observed and calculated illuminations, instead of only two profiles. Whereas Jenkner and Sinachopoulos had used the empirical function of Franz in order to empirically model the spread of illuminations of a star image resulting from both the diffraction by an aperture and the atmospheric agitation, Pierre Bacchus proposed a simpler function which better represents the real spread of illuminations, namely the product of a Cauchy-Lorentz function and a Gauss-Laplace function. Two developments were made in parallel. In the first, Guy Morlet wrote BASIC routines which read the image files and display the images on a computer screen, whereas Edgar Soulié wrote in FORTRAN a program fitting the nine parameters which define the map of calculated illuminations by minimization of the sum of squares of differences between the observed and calculated illuminations.

In the second development, Guy Morlet and Pierre Bacchus wrote in the $C$ programming language the program $S U R F A C E$ which combines the reading of the recorded image file, the parameter fitting and the display of the observed and calculated images. This program resorts to a single programming language. In 2002, Guy Morlet wrote this program again in Visual BASIC. Ancillary programs sort the selected images and combine them before the parameter fitting is applied. In order to solve particular cases involving components which are close or whose magnitude difference is important, René Gili at Nice has used the wavelet function of the IRIS program (see Buil). Double star images have been acquired during missions with the $50-\mathrm{cm}$ refractor of the Observatoire de Nice from 1997 to 2004 and measured with the SURFACE program. The measures have been published. 
Independently of CCD cameras, amateur astronomers got acquainted with webcams and used them, modified or not, for astronomical images. This new image acquisition device aroused a few new inclinations for the measure of double stars and the development of a new program $R E D U C$ in the DELPHI programming language by Florent Losse. The program connects the sorting of images, the measure on selected images and the mean of these measures. Recently, the SURFACE program was integrated in REDUC.

\section{References:}

- Pierre Bacchus, Patrick Lagrange, Guy Morlet, \& Maurice Salaman, "Mesure d'étoiles doubles à l'aide d'une camera CCD", L'Astronomie, vol. 107 (juin 1993)

- Christian Buil, CCD Astronomy, Willmann-Bell, Richmond, Virginia, USA

- Paul Couteau \& René Gili, "Mesures d'étoiles doubles faites à Nice, étoiles doubles nouvelles (24 è série) découvertes à Nice", $A \mathscr{G} A S$, vol. 106 (1994) p. 377

- André Debackère, "La mesure d'étoiles doubles avec un petit instrument", Obs. \& Travaux, no. 60 (novembre 2005), pp. 23-27

- René Gili, communication privée

- René Gili, "Measures of double stars made at the great refractor of Nice (part one)", Astronomische Nachrichten, vol. 312 (1991) p. 41

- René Gili \& Paul Couteau, "Mesures d'étoiles doubles faites aux lunettes de 74 et $50 \mathrm{~cm}$ de l'Observatoire de la Côte d'Azur", $A \mathscr{E} A S$, vol. 126 (1997) p. 1

- Florent Losse, "Mesures d'étoiles doubles réalisées à l'aide de capteurs CCD de grande diffusion", Obs. \& Travaux, no. 59 (2005), pp. 27-34

- Florence \& Pascal Mauroy, "Mesures d'étoiles doubles avec une caméra CCD", Obs. \& Travaux, no. 52 (juin 2000) pp. 47-52

- Florence \& Pascal Mauroy, "Mesures d'étoiles doubles et précision des coordonnées équatoriales", Obs. $\&$ Travaux, no. 61 (décembre 2005), pp. 10-25

- Patrick Martinez \& et Alain Klotz, "Le guide pratique de l'astronomie CCD", publisher ADAGIO, Toulouse, 1994

- Guy Morlet, Maurice Salaman, \& René Gili, "CCD measurements of visual double stars made with the 50-cm refractor of the Nice Observatory (2nd series)", $A \mathscr{E} A S$, vol. 145 (2000) p. 67

- Guy Morlet, Maurice Salaman, \& René Gili, "Observatory CCD measurements of visual double stars (4th series)", A\&AS, vol. 396 (2002) p. 933

- Guy Morlet \& Maurice Salaman, "Logiciel de mesure d'étoiles doubles sur images CCD par ajustement d'une surface de lumière (en langage C)", Obs. E Travaux, no. 61 (2005) pp. 34-48

- Maurice Salaman \& et Guy Morlet, "Sept années de mesures d'étoiles doubles visuelles sur des images acquises avec des caméras CCD", Obs. \& Travaux, no. 52 (juin 2000) pp. 63-66

- Maurice Salaman, Guy Morlet, \& René Gili, "Mesures d'étoiles doubles effectuées à la lunette de $50 \mathrm{~cm}$ de l'Observatoire de Nice avec une caméra CCD", $A \& A S$, vol. 135 (1999) p. 499

- Maurice Salaman, Guy Morlet, \& René Gili, "Nice Observatory CCD measurements of visual double stars (3rd series)", A\&AS, vol. 369 (2001) p. 552

- Maurice Salaman, Guy Morlet, René Gili, \& Daniel Bonneau, "Mesures d'étoiles doubles effectuées à la lunette de $50 \mathrm{~cm}$ de l'Observatoire de Nice avec une caméra CCD", Obs. E Travaux, no. 59 (2005) pp. 18-26

- Edgar Soulié \& Guy Morlet, "Une nouvelle méthode de détermination des éléments de position d'une étoile double", Proceedings of the international workshop Visual double stars: formation, dynamics and evolutionary tracks, J.A. Docobo, A. Elipe, H. A. McAl- 
ister editors, Kluwer Acedemic Publishers, Dordrecht, 1997, pp. 107-111 Internet site on the use of webcams for double stars measures: http://www.astrosurf.com/hfosaf /

\section{Reobservation of MLR pairs}

Between 1953 and 1989, the French astronomer Paul Muller (1910-2000) discovered ca. 700 pairs, most of them at the Nice Observatory. A few of these have given remarkable orbits, for example MLR $4=$ HIP 116849 (period of 20 years). The complete list of the MLR couples with measurements is available on the SIDONIe server at Nice Observatory. Unfortunately, these pairs are seldom reobserved because they are close and/or have a large magnitude difference, which require a high quality instrument. The $50-\mathrm{cm}$ refractor at the Nice Observatory is among them.

Number of entries in the WDS

644

MLR couples missing in the WDS

76

Percentage of pairs with separations between $0^{\prime \prime} .1$ and $0^{\prime \prime} .3 \quad 30 \%$

Percentage of pairs with less than three measures $\quad 20 \%$

Percentage of pairs not observed since 1989 (last publication) $\quad 34 \%$

Number of calculated orbits

Starting in September 2001, Pierre DURAND and Claude PINLOU have undertaken a systematic reobservation of these pairs using the 50-cm refractor of the Nice Observatory with which they were discovered and a CCD camera. They used the software SURFACE (see above). In 2006, a quarter of the program has been achieved. It unfortunately pertains to the widest pairs, probably the least interesting. The close pairs, between $0^{\prime \prime} .15$ and $0^{\prime \prime} .4$ have so far been seldom visited because the images were unstable during the five missions which have been made. A publication is in preparation. It shows that the last discoveries made by Paul Muller have not all been included in the WDS catalogue, that accurate identifications of pairs with low brightness are missing and that pairs are in motion, promising the future determination of orbits.

\section{Reference:}

- Paul Muller, "Catalogue de 700 étoiles doubles MLR", édition Obs. de la Côte d'Azur (1992).

\section{Orbit calculations}

Before the Second World War, Dr. Paul Baize had not only made measurements of pairs but also determined about 150 orbits. In 1954, he published an article in L'Astronomie in which he explained how orbits may be determined by a graphical method. In 1983, the late Michel Walbaum and Jean-Louis Duvent tackled the search for invisible companions of binary stars by investigating the perturbations which these companions induce on the orbits; their article contained a prophecy which has since been realized: We are near to discover giant planets similar to Jupiter. In 1986, Edgar Soulié published a new method for the orbit improvement of visual double stars. The corresponding software was published in Observations et Travaux. Using this and other software, René Manté started a long series of calculations of preliminary orbits of close pairs, which have been regularly published in the Information Circular of Commission no. 26 (Double Stars) of the IAU. Jean Dommanget presented the Thiele-van den Bos method. 


\section{Reference:}

- Paul Baize, "Masses of red variable stars", Sky $\&$ Telescope, 60 (1980) 13

- Paul Baize, "Orbital elements of 14 visual double stars", A $\& A S, 39$ (1980) 83

- Paul Baize, "The orbital elements of 43 visual double stars", A\&AS, 44 (mai 1981) 199

- Paul Baize, "Orbital elements for 11 visual binaries", A\&AS, 51 (mars 1983) 479

- Paul Baize, "Méthode simple pour calculer les éléments orbitaux d'une étoile double", L'Astronomie, vol. 98 (février 1984), pp. 67-74; Errata, L'Astronomie, juin 1984, p. 293

- Paul Baize, "The orbital elements of twenty-eight visual binaries", $A \& A S, 56$ (april 1984) 199

- Paul Baize, "The orbital elements of fifteen visual binaries", A\&AS, 60 (mai 1985) 333

- Paul Baize, "Sur deux étoiles doubles à courte période 51 Tauri et Nu Bootis", L'Astronomie, vol. 100 (juin 1986), pp. 291-295

- Paul Baize, "The orbital elements of twenty-one visual binaries", A\&AS, 65 (septembre 1986) 551

- Paul Baize, "The orbital elements of twenty-eight visual binaries", $A \mathscr{G} A S, 56$ (april 1984) 199

- Paul Baize, "Orbits of WDS 00122+0819, WDS 01147-0101, WDS 15020+0154, WDS 18400+3135 and WDS 22336+7221", IAU Commission 26 (Double Stars) Information Circular no. 101 (February 1987)

- Paul Baize, "Orbits of WDS 02528+2344, WDS 02555-1141 WDS 04346+5920, WDS 06486+5833 and WDS 17207+3840", IAU Commission 26 (Double Stars) Information Circular no. 102 (June 1987)

- Paul Baize, "The orbital elements of 26 double stars", A\&AS, 71 (October 1987) 177

- Paul Baize, "New Orbits of WDS 05533+1248, WDS 06107-0900, WDS 13090-2345, WDS 13124-0009, WDS 17496+1108, WDS 19295+5824 and WDS 19429+1817", IAU Commission 26 (Double Stars) Information Circular no. 103 (October 1987)

- Paul Baize, "New Orbits of WDS 00447+6342, WDS 02367+1935, and WDS 16309+4238", IAU Commission 26 (Double Stars) Information Circular no. 104 (February 1988)

- Paul Baize, "New Orbits of WDS 09129+2114, WDS 10532+1744, WDS 17067-0144, WDS 18081+3325", IAU Commission 26 (Double Stars) Information Circular no. 105 (June 1988)

- Paul Baize, "New Orbits of WDS 00376+2014, WDS 00463-2205, WDS 02156+2108, WDS 03138-0124, WDS 06442+2416, WDS 08252+3518, WDS 10017+7537 and WDS 18538-1258", IAU Commission 26 (Double Stars) Information Circular no. 106 (November 1988)

- Paul Baize, "L'observation des étoiles doubles et le calcul de leurs orbites",

L'Astronomie, vol. 102 (décembre 1988) 476

- Paul Baize, "Sur le mouvement relatif de l'étoile double ADS3596 = STT 93",

L'Astronomie, vol. 103 (1989) 199

- Paul Baize, "New Orbits of WDS 11369-1221, WDS 11551+4629, WDS 16317-0215, WDS 18374+7441, WDS 18462+6412, WDS 19419+4015 and WDS 21001+4004", IAU Commission 26 (Double Stars) Information Circular no. 107 (February 1989)

- Paul Baize, "Orbital elements of 12 visual binary stars", A\&AS, 78 (April 1989) 125

- Paul Baize, "New Orbits of WDS 00335+4006, WDS 04185+2135, WDS 05417-0254, WDS 06383+2859, WDS 08231+2001, WDS 09474+1134, WDS 12199-0040, 
WDS 13202+1747, WDS 14403+2158, WDS 16341+4227, WDS 17420+1557,

WDS 19311+5835, WDS 19348+2928 and WDS 21080+0509", IAU Commission 26 (Double Stars) Information Circular no. 109 (October 1989)

- Paul Baize, "Orbital elements of eight interferometric binary stars", A\&AS, 81 (December 1989) 415

- Paul Baize, "New Orbits of WDS 01198-0029, WDS 13320+3109, WDS 17217+3958", IAU Commission 26 (Double Stars) Information Circular no. 110 (February 1990)

- Paul Baize, "New Orbits of WDS 00310-1005, WDS 02287+3215, WDS 06290+2014, WDS 06418+3041, WDS 06474+1812, WDS 06528+2459, WDS 15370+6425, WDS 21080+0509", IAU Commission 26 (Double Stars) Information Circular no. 111 (June 1990)

- Paul Baize, "New Orbits of WDS 07508+0317, WDS 16057-0617, WDS 16212+2259, WDS 17490+3704, WDS 17543+1108, WDS 19599-0957, WDS 21511+6650,

WDS 22241-0451", IAU Commission 26 (Double Stars) Information Circular no. 112 (October 1990)

- Paul Baize, "Orbital elements of 17 binary stars", A\&AS, 87 (January 1991) 49

- Paul Baize, "New Orbits for WDS 02210+4247, WDS 15492+6032,

WDS 17399-0039", IAU Commission 26 (Double Stars) Information Circular no. 113 (February 1991)

- Paul Baize, "New Orbit for WDS 20474+3629", IAU Commission 26 (Double Stars) Information Circular no. 114 (June 1991)

- Paul Baize, "New Orbits of WDS 05373+6642, WDS 06171+0957, WDS 06573+5825, WDS 08269+3212, WDS 09379+4554, WDS 14557+3939, WDS 19180+2012,

WDS 20311+3332", IAU Commission 26 (Double Stars) Information Circular no. 115 (October 1991)

- Paul Baize, "Orbital elements of 17 binary stars", A $\& A S, 92$ (January 1992) 31

- Paul Baize, "New Orbits of WDS 04465+4220, WDS 07561+2342, WDS 15390+2545, WDS 16137+4639, WDS 17221+2310", IAU Commission 26 (Double Stars) Information Circular no. 116 (February 1992)

- Paul Baize, "New Orbits of WDS 01013+1156, WDS 18063+3824, WDS 20232+2052, WDS 21556+3849", IAU Commission 26 (Double Stars) Information Circular no. 117 (June 1992)

- Paul Baize, "New Orbits of WDS 03283+6015, WDS 04275-2428, WDS 08017+6019, WDS 08231+2001", IAU Commission 26 (Double Stars) Information Circular no. 119 (February 1993)Paul Baize, Orbital elements of 19 binary stars, A\&AS, 99 (June 1993) 205

- Paul Baize, "New Orbits of WDS 09207-0742, WDS 10083+3137, WDS 12160+4807, WDS 13583+0213, WDS 15136+3453, WDS 15420+0028, WDS 17572+2400,

WDS 22307+1759", IAU Commission 26 (Double Stars) Information Circular no. 120 (June 1993)

- Paul Baize, "New Orbits of WDS 03320+4341, WDS 03423+3141, WDS 16384+3514, WDS 17075+3810, WDS 18043+4206, WDS 22077+2622, WDS 23199+2845", IAU Commission 26 (Double Stars) Information Circular no. 121 (October 1993)

- Paul Baize, "Elements orbitaux de douze étoiles doubles", A\&AS, 106 (August 1994) 267

- Jean Dommanget, "La méthode de Thiele-van den Bos pour le calcul de l'orbite d'une étoile double visuelle", Obs. \& Travaux no. 52 (juin 2000) pp. 19-25

- René Manté, "Première orbite de COU 1462", Obs. $\&$ Travaux, no. 39 (1994) pp. $21-28$ 
- René Manté, "Orbite provisoire pour les étoiles doubles COU 1757 et COU 1462", Obs. \& Travaux, no. 52 (1997) pp. 44-46

- René Manté, "Orbits of WDS 14260+4213 and WDS 16216+3631", IAU Commission 26 (Double Stars) Information Circular no. 134 (February 1998)

- René Manté, "New orbit of WDS 14260+4213", IAU Commission 26 (Double Stars) Information Circular no. 136 (October 1998)

- René Manté, "Orbits of WDS 01345+3440, WDS 09175+7715 and

WDS 20151+3742", IAU Commission 26 (Double Stars) Information Circular no. 137 (February 1999)

- René Manté, "Orbits of WDS 06598+3141 and WDS 19089+3404", IAU Commission 26 (Double Stars) Information Circular no. 138 (June 1999)

- René Manté, "Orbit of WDS 12316+3201", IAU Commission 26 (Double Stars) Information Circular no. 139 (October 1999)

- René Manté, "Orbit of WDS 10454+3831", IAU Commission 26 (Double Stars) Information Circular no. 140 (February 2000)

- René Manté, "Orbit of WDS 03320+4341", IAU Commission 26 (Double Stars) Information Circular no. 141 (June 2000)

- René Manté, "Orbits of WDS 16450+2928 and WDS 21000+4004", IAU Commission 26 (Double Stars) Information Circular no. 142 (October 2000)

- René Manté, "Orbits of WDS 06502+3624 and WDS 17136+1716", IAU Commission 26 (Double Stars) Information Circular no. 143 (February 2001)

- René Manté, "Orbits of MLR 314 (WDS 05372+6642) and COU 100 (WDS 14459+2344)", IAU Commission 26 (Double Stars) Information Circular no. 144 (June 2001)

- René Manté, "Orbits of WDS 00576+5424, WDS 07324-3558 and WDS 17088+6543", IAU Commission 26 (Double Stars) Information Circular no. 145 (October 2001)

- René Manté, "Two Orbits of MCA 25(WDS 06073+2641), and an orbit of MCA 35 (WDS 11159+1318 and WDS 17088+6543", IAU Commission 26 (Double Stars) Information Circular no. 146 (February 2002)

- René Manté, "Orbits of WDS 07003-2207 and WDS 21118+5959", IAU Commission 26 (Double Stars) Information Circular no. 147 (June 2002)

- René Manté, "Orbits of WDS 11441-0448 and WDS 21593+4606", IAU Commission 26 (Double Stars) Information Circular no. 148 (October 2002)

- René Manté, "Orbits of WDS 04464+4221 and WDS 14567-6247", IAU Commission 26 (Double Stars) Information Circular no. 149 (February 2003)

- René Manté, "Orbits of WDS 08275-5501 and WDS 12270-0332", IAU Commission 26 (Double Stars) Information Circular no. 150 (June 2003)

- René Manté, "Orbits of WDS 08474-1703 and WDS 10465-6416", IAU Commission 26 (Double Stars) Information Circular no. 151 (October 2003)

- René Manté, "Orbits of WDS 04464+4221, WDS 15513-0305 and WDS 22344+2623", IAU Commission 26 (Double Stars) Information Circular no. 152 (February 2004)

- René Manté, "Orbits of WDS 13574-6229 and WDS 17248+3044", IAU Commission 26 (Double Stars) Information Circular no. 153 (June 2004)

- René Manté, "Orbits of WDS 13145-2417 and WDS 21543+1943", IAU Commission 26 (Double Stars) Information Circular no. 154 (October 2004)

- René Manté, "Orbits of WDS 02193+5338, WDS 07269+2015, WDS 12446-5717 and WDS 12597-0349", IAU Commission 26 (Double Stars) Information Circular no. 155 (February 2005)

- René Manté, "Orbits of HU 972 AB (WDS 21511+6650) and COU 432 BC (WDS 
21543+1943)", IAU Commission 26 (Double Stars) Information Circular no. 156 (June $2005)$

- René Manté, "Orbit of WDS 01554+0257", IAU Commission 26 (Double Stars) Information Circular no. 157 (October 2005)

- René Manté, "Orbit of FIN 367 Aa (WDS 12064-6543)", IAU Commission 26 (Double Stars) Information Circular no. 158 (February 2006)

- Edgar Soulié, "Une méthode d'amélioration de l'orbite d'une étoiles double visuelle", A\&A, 164 (1986) pp. 408-414

- Edgar Soulié, "La détermination de l'orbite d'une étoile double visuelle par le calcul. Méthode et programmes, Première partie", Obs. \& Travaux, no. 35 (Troisième trimestre1993) pp. 7-19

- Edgar Soulié, "La détermination de l'orbite d'une étoile double visuelle par le calcul. Méthode et programmes, Seconde partie", Obs. \& Travaux, no. 37 (Premier trimestre 1994) pp. 13-27

- Michel Walbaum \& Jean-Louis Duvent, "A la recherche des compagnons invisibles des étoiles doubles", L'astronomie, juin 1983, pp. 277-289

\section{History of double star observers}

Jean-Claude THOREL has published a biography of Robert Jonckheere, at first an amateur who devoted his life to double stars and created his observatory at Hem in the vicinity of Lille (département du Nord). Due to the First World War, Robert Jonckheere sought refuge in England and made observations at Greenwich Observatory. In 1930, his equipment was sold to the University of Lille, which created a new observatory in 1934, which houses the 35-cm refractor. Robert Jonckheere became a professional astronomer and ended his career at the Observatory of Marseilles. Jean-Claude Thorel published an obituary of Paul Muller. In an article, Edgar Soulié summarized the activities of French astronomers, whether professional or amateur, involved in double star studies from the origin of the field until the present.

\section{Reference:}

- Robert Jonckheere, "Recherche d'étoiles doubles nouvelles", L'Astronomie, vol. 56 (novembre 1942) p. 171

- Edgar Soulié, "French astronomers, visual double stars and the Double star working group of Société Astronomique de France", in Proceedings of the third Asian double star conference, Kam Ching Leung editor, ASP Conf. Series no. 130 (1997) p. 291

- Jean-Claude Thorel, "Robert Jonckheere un Roubaisien astronome à Hem", l'Observatoire de Hem puis de Lille, éditeur Mairie de Hem, 1999

- Jean-Claude Thorel, "Paul Muller (1910-2000)", IAU Commission 26 (Double Stars) Information Circular no. 141 (June 2000)

- Jean-Claude Thorel, "Paul Muller (1910-2000)", L'Astronomie, vol. 114 (JuilletAoût 2000) p. 287

- Jean-Claude Thorel, "Robert Jonckheere (1888-1974) Le dernier observateur au télescope de Foucault", résumé de l'exposé présenté au colloque du tricentenaire de l'Observatoire de Marseille, octobre 2002

- Jean-Claude Thorel, "Robert Jonckheere et les étoiles doubles. Qu'en est-il des mesures?", Obs. ES Travaux, no. 61 (décembre 2005) pp. 26-33 


\section{The Internet site of the Commission:}

After a period of creation and testing, the Internet site of the Commission created by Sébastien CAILLE was opened in january 2006 at the address:

http://saf .etoilesdoubles.free.fr In development, this site is bound to evolve with contributions of members of the Commission. It has the purpose to make the activities of the Commission known and to arouse vocations within the community of amateur astronomers. The column "Articles/documents" makes available in electronic form the book of the honorary president of the Commission Paul Couteau entitled L'observation des étoiles doubles visuelles (Flammarion Paris, 1978) articles and miscellaneaous documents relevant to binary stars. The column "Outils" offers the possibility to load or to connect oneself to several tools which are useful for double star observers. One of them is a search engine for double stars recorded in the WDS catalogue: http://doublestars.free.fr, developed by Sébastien CAILLE. Software specific to reduction of double star data can also be loaded. The column "Observation" presents the observation projects as well as calls for observations.

\section{International contacts}

The Double Star Committee established contact with foreign amateur astronomers, among them Andreas Alzner in Germany, Tamas Ladanyi in Hungary, Jordi Cairol, Jaime Planas, Francisco Rica Romero, coordinator of the Liga Ibero Americana De Astronomia (LIADA), Tofol Tobal in Spain, Robert Argyle, president of the Webb Society, John Larard, Chris Lord and in the United Kingdom, Brian Mason, William Hartkopf, and Ronald Tanguay in the United States. The contact with Spanish amateurs resulted in a joint meeting between Spanish and French double star amateurs which took place at Castelldefels (Catalunya) in Spain in October 2000. Florent Losse, deputy editor of the journal Observations et Travaux, sends the electronic files of the double star measures published in this journal to William Hartkopf at the United States Naval Observatory for inclusion in the WDS catalogue of measures. Tofol Tobal contributed an article for the special issue on double stars and Tamas Ladanyi published an astronomical biography of the Hungarian amateur Erno Berko in a recent issue of the journal Observations et Travaux. Josefina Ling, scientific adviser, published an article describing an observatory and Robert Argyle published a presentation of the Webb Society and its double star section in L'Astronomie.

\section{Reference:}

- Robert Argyle, "La section des étoiles doubles de la Webb Society", L'Astronomie, vol. 120 (janvier 2006) pp. 463-464

- Tamas Ladanyi, "Un dupliciste hongrois: Erno Berko", Obs. E Travaux, no. 60 (november 2005) pp. 21-22

- Josefina Ling, "L'observatoire de Llano del Hato", L'Astronomie, vol. 116 (décembre 2002)

- Tofol Tobal, "Mesures d'étoiles doubles visuelles", Obs. \& Travaux, no. 52 (juin 2000) pp. 67-72

\section{Eclipsing binaries studied by a sister group}

Independently of the Commission, the "Groupe Etudes et d'Observations Stellaires" made observations of eclipsing binaries which were published in Observations \& Travaux and L'Astronomie. 


\section{Reference:}

- Nicola Beltraminelli \& Davide Dalmazio, "L'étoile variable NSV 11321 Lyr", Obs. \& Travaux, no. 52 (juin 2000) pp. 3-7

- Michel Dumont \& Roland Boninsegna, "Observations de l'étoile NSV 12040", L'Astronomie, vol. 101 (mai 1987) pp. 315-319 